\title{
DE DIVINAÇÕES XAMÂNICAS E ACUSAÇÕES DE FEITIÇARIA: IMAGENS WAUJA DA AGÊNCIA LETAL*
}

\author{
Aristóteles Barcelos Neto
}

Entre os Wauja ${ }^{1}$ do Alto Xingu, a elaboração dos domínios da feitiçaria e do xamanismo realiza-se por meio de um esforço de descontinuidade epistemológica entre ambos. Os feiticeiros não são, como os xamãs, figuras públicas; eles existem, sobretudo, no plano das acusações. Pretendo demonstrar que o manejo conceitual desse plano é fundamental para a construção da dimensão visionário-divinatória do xamanismo e da cosmopolítica wauja. Apesar da descontinuidade entre feitiçaria e xamanismo, há momentos, como nas práticas de contrafeitiçaria (tũpaki), em que ocorre um cruzamento epistemológico entre ambos.

Em certas regiões das Terras Baixas da América do Sul, como no Noroeste Amazônico (Reichel-Dolmatoff 1975), nas Guianas (Sztutman 2000, 2005) e na Amazônia Oriental (Fausto 2001; Teixeira-Pinto 2004), o xamanismo tem uma natureza bipolar, ou seja, pode tanto curar quanto agredir/matar. Este não é o caso do Alto Xingu, onde as técnicas do xamanismo e da feitiçaria são bastante distintas. A própria gnosiologia da agência patológica não situa a feitiçaria como uma prática maléfica de xamanismo. Quero insistir na separação entre xamanismo e feitiçaria não apenas por ser ela um claro dispositivo êmico de classificação das relações sociocosmológicas no Alto Xingu, mas porque tal separação permite refletir sobre aspectos ainda obscuros do sistema xinguano (Coelho de Souza 2001) e confrontá-los com as ontologias amazônicas da predação (Viveiros de Castro 2002a, 2002b; Fausto 2001, 2002).

\section{A diferença centrada no corpo}

A doença grave é a relação modelar entre humanos e não-humanos, à qual corresponde o rapto da alma (princípio vital, consciência) do doente pelos apapaatai — os seres prototípicos da alteridade, basicamente caracteri- 
zados por animais e monstros "mascarados" (veja discussão detalhada na terceira seção). Seqüências mais ou menos contínuas de raptos permitem a fragmentação e a distribuição da alma entre uma diversidade considerável de apapaatai, cada qual ligado a rituais específicos e inter-relacionados. Em sua companhia, as almas passarão a alimentar-se das comidas dos "bichos" - carne crua ou podre, sangue, capim, folhas — que obviamente não fazem parte da dieta wauja. Essa mudança alimentar e o convívio com os apapaatai desencadeiam um processo de múltipla animalização do doente e, através dele, as suas almas começam a adquirir as formas e os pontos de vista dos apapaatai que as raptaram e, dentro de algum tempo, cada fragmento de alma será como um deles. A desanimalização, ou melhor, a cura de doenças graves só pode ser feita por xamãs visionário-divinatórios (yakapá) e especialistas rituais (kawoká-mona) que processam uma série de ações em planos sucessivos e interdependentes. Apenas os xamãs podem reordenar os domínios humano e animal misturados em um sujeito doente. A retirada de substâncias introduzidas pelos apapaatai, na forma de flechinhas, no corpo do doente é o primeiro passo para facilitar o resgate das frações-alma e para a recuperação da perspectiva humana do doente.

Embora a feitiçaria (ixanaki) e o xamanismo (yatamaki) estejam basicamente voltados para o corpo dos doentes, os Wauja consideram ambas as atividades como profundamente antagônicas. Enquanto a primeira produz ou aproveita o estado grave dos doentes para matá-los através da introdução de microobjetos letais, a segunda procura curá-los, ou seja, busca reintegrar o corpo e os fragmentos da alma do doente.

A aproximação conceitual da doença e da morte aos modelos ontológicos da predação (Viveiros de Castro 2002a, 2002b; Fausto 2002) permite-nos visualizar como o esquema contínuo-gradativo que orienta a cosmologia xinguana (Viveiros de Castro 2002c; Barcelos Neto 2004a, 2006 e no prelo) vê a morte como um efeito que encadeia a apreensão de almas (rapto/doença grave) ao assassinato (como feitiçaria).

Quando alguém está prestes a morrer por uma ação de feitiçaria, ele é capaz, algumas vezes, por meio de uma visão onírica, de reconhecer seu "assassino". O moribundo consegue antecipar algo que os viventes apenas saberão após um longo processo de divinação xamânica. Os xamãs wauja dizem que a capacidade de adivinhação do moribundo se deve às fortes dores que ele sente. Mas em sua agonia dificilmente ele consegue dizer aos viventes quem ou o que ele viu. Para os viventes, a morte de alguém atualiza uma potência letal que a comunidade deseja expurgar. Para os consangüíneos do morto, a sua morte funde os domínios privado e público, levando a uma empreitada divinatória e a uma perseguição do "assassino", ou melhor, do feiticeiro acusado. ${ }^{2}$ Esta é a rigor uma perseguição 
arriscada que, em muitos casos, precisa ser suspensa, pois a exposição excessiva do acusador e do acusado corrói os princípios estéticos da etiqueta xinguana, gerando uma abertura para um novo assassinato, neste caso, traduzido como vingança do acusador (voltaremos ao assunto nas seções seguintes).

Mencionei anteriormente (Barcelos Neto 2001, 2002) o trânsito de substâncias patogênicas entre feiticeiros e seres sobrenaturais (apapaatai). Retomo aqui o tema a partir de uma outra base. Se a causa primeira da morte é de ordem interior ao socius, ela então existiria como uma prática entre parentes, entre "iguais". Mas seria o feiticeiro um "igual"? Qual o seu nível de "interioridade"? Seria ele propriamente humano? Ou melhor, qual a sua posição de identidade/alteridade no sistema? Por manipular feitiços, livremente e sem seqüelas graves, o feiticeiro não pode ser, conforme os pressupostos ontológicos que distribuem os predicados da humanidade, essencialmente humano. Uma grande parte desses predicados está centrada no corpo, isto é, nos seus processos de fabricação (cf. Viveiros de Castro 1977, 2002c).

Quase todo feiticeiro descende de um feiticeiro, pois é dito pelos Wauja que a feitiçaria é um saber transmitido de pai para filho ou de avô para neto, mas também seria possível aprender o ofício letal em um suposto círculo restrito de feiticeiros. Somente um feiticeiro é capaz de fazer outro feiticeiro. Não se trata apenas de um saber transmitido, mas sobretudo de uma incorporação, que é devida a um tipo especial de reclusão, na qual o tempo do jovem feiticeiro é investido em atividades como suportar doloridíssimas picadas de formigas tocandira (mẽ̃̃, em wauja - elas são as companheiras dos feiticeiros e o modelo animal da alta feitiçaria) e o calor de objetos incandescentes. Viveiros de Castro (1977:227) expõe a diferença primordial entre o feiticeiro e o xamã: "o que distingue o feiticeiro do xamã é que aquele 'só tem feitiço guardado no mato' (é um tecnólogo do mal); o xamã tem yutši ${ }^{3}$, poder curativo inefável". O primeiro é imaginado recebendo sua formação em privado, por um genitor masculino, e o segundo, em público, com iniciação e apresentações formais desde a casa das flautas (kuwakuho).

Os feiticeiros são também hábeis na "fala feia" (aitsa-awojogatakoja), ou melhor, na capacidade de distorcer e de falsear fatos: "sua língua não é boa", "eles sabem fazer o pessoal brigar", dizem os Wauja dos feiticeiros. Por suportarem e provocarem dores terríveis, seus corpos assemelham-se aos dos seres prototípicos da feitiçaria (em geral animais peçonhentos, alados e com ferrão). Um feiticeiro recluso não bebe as mesmas ervas e raízes que um jovem lutador; este toma um emético que tem os felinos como "donos" (wekeho), seu corpo é fabricado em uma relação de homologia com as onças, os grandes lutadores. Já o jovem aprendiz da feitiçaria bebe os eméticos que têm como "donos" os animais feiticeiros. Nenhuma pessoa foi capaz de 
mencionar os nomes desses eméticos, apenas me disseram que são outros que aqueles usados por não-feiticeiros. Sei que a maldade de um feiticeiro é elaborada por meio do uso, na reclusão, de certas substâncias vegetais, pois valores morais podem ser adquiridos/mudados através da manipulação dessas substâncias. Há uma categoria de "feitiço" especialmente com esse objetivo, o kuretsi.

Love magic é a tradução dada por Gregor (1977:88) ao kuretsi (kuritsi, em mehinako). O kuretsi está por trás de muitas brigas entre mulheres, que acusam umas às outras de o terem usado para enfeitiçar seus maridos. O kuretsi leva o homem a pensar permanentemente em sua namorada "feiticeira", fazendoo esquecer de suas obrigações domésticas, causa de muitos conflitos entre casais. A mulher que manipula kuretsi não quer apenas um amante, mas sim um homem loucamente apaixonado e, além disso, contentar-se com o ciúme provocado em outra mulher.

Quem manipula o kuretsi também corre risco: se usado de modo errado ou excessivo, o seu efeito será inverso. Acompanhei, durante dois meses, o drama de uma mulher que passou por essa situação. Apaixonada por um não-índio, ela abandonou o marido e fugiu com o amante. Levada de volta para Piyulaga, a aldeia wauja, ela passou a receber tratamentos com eméticos a fim de neutralizar o efeito do kuretsi em sua "cabeça". Seu pai, que lhe ministrava diariamente os eméticos (contrafeitiços), tinha convicção de que sua filha havia manipulado desastradamente o kuretsi: "kuretsi mudou a cabeça dela, por isso a cabeça dela ficou ruim", disse-me ele em privado, com vergonha do comportamento da filha. O kuretsi não é, pois, apenas love magic, ele age sobre a consciência e o comportamento de um modo geral, podendo inclusive apagar a memória de alguém sobre algum fato recémocorrido. Um hábil manipulador de kuretsi pode usá-lo para fazer com que uma testemunha de algo nefasto esqueça-se do que viu. Quando as crianças ficam repentina e/ou prolongadamente agressivas e inquietas, o kuretsi é também uma hipótese aventada. No entanto, o kuretsi não mata.

Os métodos de fabricação do corpo de um feiticeiro resultam em um ser feio, fraco, mal lutador, pouco hábil em várias artes e ofícios, de personalidade imprevisível e socialmente retraída. Além disso, ele tem pequena estatura, abdômen saliente, joelhos e cotovelos inchados e pernas e braços finos (cf. também Carneiro 1977:225). Mas esta é apenas uma imagem ideal que, na verdade, afina a identidade corporal dos feiticeiros com certos seres sobrenaturais, em especial os apapaatai antropomorfos donos de cabacinhas e de roupas-adornos-feitiços (Barcelos Neto 2001, 2002; Fénelon Costa 1988). Assim, a condição "humana" de um feiticeiro pode ser diretamente contestada pelas características do seu corpo que, como categoria idealizada, é a mais perfeita 
antítese do chefe (amunaw) e do xamã (yakapá). A construção dessa antítese é formalizada nos discursos públicos dos chefes, como se pode perceber na fala de Akusa, um antigo chefe mehinako, a respeito dos Ikpeng:

Sejam como eu. Eu não sou um feiticeiro. No Posto (Leonardo Villas Bôas) há muitos Txicão (Ikpeng). Eles disseram, "nós mataremos Akusa; nós já o atingimos com uma flecha (de feitiço)!" Eu sei que eles querem me matar. Se eu fosse feiticeiro, eu os teria matado há muito tempo, cada um deles, mas vejam: suas mulheres estão grávidas e seus bebês estão gordos. [Portanto] Eu não poderia ser um feiticeiro! (Gregor 1977:82).

Akusa constrói em seu discurso uma auto-imagem inversa a dos Ikpeng que, neste caso, serviram como um contraponto dificilmente contestável, pois percebidos como bravos e aguerridos, os Ikpeng apresentavam, aos olhos dos Mehinako, os atributos típicos de feitiçaria. É sobre a aproximação entre guerra e feitiçaria que passo a tratar.

\section{Chefia, guerra e a feitiçaria como assassinato}

As relações entre chefia, guerra e feitiçaria foram exploradas de modo bastante interessante por Patrick Menget $(1985,1993)$, Menezes Bastos (1995) e mais recentemente por Coelho de Souza (2001). Mas o assunto não é recente. Ele surge nas primeiras etnografias sistemáticas na região, realizadas na década de 1950 por Robert Carneiro e Gertrud Dole e, anos mais tarde, na monografia de Ellen Basso (1973).

Menget (1985) circunscreve a feitiçaria xinguana no mesmo campo simbólico da guerra, sugerindo que a sua supressão teria sido compensada pela sua atualização cotidiana como feitiçaria. Assim, o pacifismo xinguano seria apenas aparente: os xinguanos não fazem guerra ipso facto, mas se matam em função de acusações de feitiçaria: o epifenômeno de guerras faccionais (Menget 1993). Entretanto, não é porque a feitiçaria condensa um princípio de agressão e morte que ela necessariamente reforce esta interpretação. Parece-me, à luz dos dados wauja, que guerra e feitiçaria não estão precisamente no limiar uma da outra.

A exegese mehinako apresentada por Gregor afirma que a guerra é atualmente ocupada pelos rituais e não pela feitiçaria: "nós não fazemos guerra; temos festivais para os chefes, aos quais todas as aldeias comparecem. Nós cantamos, dançamos, trocamos e lutamos" (Gregor apud Coelho de Souza 2001:388). Por outro lado, se tomarmos alguns mitos como exemplo, 
percebe-se que esta substituição (transformação) da guerra pelo (em) ritual não é tão simples e direta como sugere o exegeta mehinako.

O primeiro Kaumai (Kwarìp, em kamayurá) foi uma guerra na qual Kamo (Sol) tentou exterminar seus convidados, os povos-peixe (Kupatopoho) e os povos-ariranha (Ewejopoho). Em outro ritual interaldeão, os povos-peixe foram convidados a tocar Kawoká (trio de flautas de madeira) pelos povos-abelha (Mapapoho), que lhes ofereceram mingau envenenado. O ritual guarda em seu fundo mítico uma potência beligerante ${ }^{4}$; é uma festa que pode ser equivalente a uma guerra não-declarada, ou melhor, a uma emboscada. Esta ambivalência paira sobre várias narrativas míticas a respeito da origem dos grandes rituais. A mais eloqüente talvez seja sobre o ritual de "furação de orelha" (Pohoká) que foi, ele próprio, uma tentativa de homicídio de Kamo contra Kamukuwaká (um jovem em idade de reclusão) e seus consangüíneos masculinos de mesma geração. Kamo, o idealizador da festa-massacre, colocou todos os pohokaixê (os iniciandos) sentados em linha, de costas para a kuwakuho (casa das flautas) e, de uma certa distância, atirou-lhes flechas; espertos, os jovens desviaram-se delas, deixando-as furar apenas os lóbulos de suas orelhas ao invés de matá-los. Assim, todos os pohokaixê tiveram suas orelhas furadas por Kamo, dando origem ao ritual. Mas as suas tentativas de massacre não pararam até que todos os pohokaixê subissem ao céu por uma escada de flechas feitas por Kamukuwaká.

No ritual Pohoká atualmente realizado entre os xinguanos, os furadores posicionam-se de joelhos em frente aos iniciandos, como se aqueles fossem partir para uma luta contra estes. Mas é no Yawari que o clima de hostilidade pode vir à tona mais explicitamente, com a utilização de pregos ou de pontas de anzóis escondidos sob a cera dos dardos, entre outros desrespeitos às regras da festa, os quais também não faltam no kapi, luta que marca a presença dos convidados nos rituais Kaumai e Yamurikumã. Aliás, a luta, como disse Viveiros de Castro, "simboliza a tensão entre estranheza e proximidade", é uma "violência codificada, estilizada" (1977:218), não deixando de ser, portanto, uma hostilidade contida. Através desta leitura, os rituais multicomunitários xinguanos parecem menos celebrações de paz (cf. Gregor 2001) do que negociações de aceitabilidades estético-morais, como propõe Menezes Bastos $(1990,1995)$. Eles são expressões de uma tensão controlada, segundo Agostinho (1974).

A hipótese de que o ritual interaldeão teria "substituído" a guerra pode ser indagada de outro modo: a guerra pode não ser logicamente oposta ao ritual, uma guerra é passível de ser tanto um ritual como este de ser uma guerra. Os próprios mitos xinguanos e as etnografias tupi (Fausto 2001) e guarani (Montardo 2001, 2002) ${ }^{5}$ apontam para alguma validade deste argumento. 
Se no Alto Xingu a feitiçaria se acomodasse à lógica da guerra, ela seria menos uma guerra contra o "outro" (índio "bravo", não-xinguano) do que uma guerra de tipo intestina ou interfaccional, segundo Menget (1993). O seu âmbito seria o do "nós", pelo menos daqueles que compartilham o mesmo ethos. Os xinguanos raramente acusam os distantes Yudjá, Kayabi ou Suyá, mas acusam, por exemplo, indivíduos de sua própria aldeia natal ou de residência. Este é o padrão mais recorrente das acusações de feitiçaria, como também observou Basso (1973) e Ireland (1986, 1988, 1993, 1996). A feitiçaria é algo que ronda a vizinhança. Não vem de muito longe. É uma agressão que dificilmente foge do mundo dos xinguanos (putakanãu), a fronteira mais nítida de sua validade moral. Neste caso, é interessante tomar como contraponto os habitantes do norte do Parque Indígena do Xingu, que têm os xinguanos como sujeitos privilegiados de suas acusações de feitiçaria (Lima 2002). Os xinguanos são incorporados pelos habitantes do norte do Parque para produzirem interpretações locais e extralocais, mas o inverso não apresenta correspondência.

As ações de feiticeiros podem ser a causa de simples irritações cutâneas até grandes ataques de porcos às roças, epidemias e incêndios de casas e aldeias (Carneiro 1977), mas o principal valor sociocosmológico da feitiçaria é, sem dúvida, ser uma prática letal. Entre os Wauja, raríssimas são as mortes que não tiveram a feitiçaria como causa principal ou complementar.

Os Wauja vêem a feitiçaria como assassinato, ela é sempre um ato de subtração absoluta. Já a imagem evocada pelas guerras históricas contra os Suyá e os Ikpeng, por exemplo, é basicamente a do rapto que, pelo lado do grupo atacado, é percebida como subtração de indivíduos, mas pelo lado do raptor é vista como soma. Esse mesmo desequilíbrio subtração-soma pode ser corrigido ou acentuado com um contra-ataque, cuja razão se voltará também para o rapto de mulheres e/ou de crianças. Os ataques-surpresa que os Wauja fizeram contra os Ikpeng atentam para isso e não para o seu extermínio por meio de uma retaliação. Um dos poucos ataques-surpresa presentes na memória dos Wauja teve lugar na década de 1950 e foi destinado a resgatar duas crianças e a raptar algumas crianças ikpeng, se tivessem sorte. Mas essa sorte os Wauja nunca tiveram, apesar de na época estarem melhor armados que os Ikpeng. Sugiro mesmo que feitiçaria (como assassinato) e guerra (como rapto) ocupam primariamente campos distintos na economia simbólica da alteridade. A aproximação entre ambas seria apenas secundária.

Para os Wauja, todo ato de feitiçaria letal deve ser vingado para impedir novas mortes. Por sua vez, os efeitos dos conflitos bélicos e/ou o seu congelamento no Alto Xingu tiveram desdobramentos muito mais complexos e variados que a pura vingança contra um feiticeiro. A guerra e a sucessiva pax 
xinguana criaram, ao longo do século $\mathrm{XX}$, redes de parentesco e de trocas xamânicas wauja-ikpeng e wauja-suyá que ainda estão por serem investigadas. É certo que no bojo das negociações da pax xinguana, mediadas pelos irmãos Villas Bôas, estava prescrita a suspensão/contenção das execuções de feiticeiros (Menezes Bastos 1995). Mas essa recomendação foi pouquíssimo seguida, possivelmente porque os xinguanos nunca perceberam as execuções de feiticeiros como uma questão própria da pax xinguana. Aceitar os casamentos arranjados pelos irmãos Villas Bôas parecia sim um princípio da pax. Afinal, este é um dos modos com que o sistema multicomunitário xinguano move e mantém suas fronteiras.

Ireland (1986, 1988, 1993, 1996) defende o argumento de que ser acusado de feitiçaria é o resultado de uma condição politicamente imputada. O que leva a supor que os acusados, os exilados e os executados como feiticeiros seriam, acima de tudo, adversários pessoais e políticos dos seus acusadores e algozes. Os Wauja são enfáticos em dizer que os feiticeiros são movidos pela raiva (musixapai) ${ }^{6}$ e pela inveja-ciúme (ukitsapai) ${ }^{7}$, e não pelo desejo de poder político. De todo modo, o feiticeiro incorpora uma imagem de poder. Porém, já que esse poder opera apenas em uma esfera oculta, ele não assume o foro público necessário para torná-lo fundamentalmente político. O seu poder de matar é antipolítico, pois ele redunda em desrespeito: o feiticeiro é alguém por quem não se tem respeito. Dele só se tem medo. Se alguém deseja "respeito" (monapaki), categoria básica da economia moral do poder no Alto Xingu, não será através de feitiçaria que ele irá conseguir. A feitiçaria em si não é uma artimanha política. Apenas aquilo que é tido como seu resultado, o assassinato, pode ser revestido de sentido político. Para os Wauja, os feiticeiros matam não porque eles desejam poder, mas porque eles são maus e egoístas. Sua maldade não tem propósitos fora de si mesma, mas seus efeitos são compreendidos por um idioma político.

As contribuições de Ireland (1986, 1988, 1993, 1996) mostram como a contestação e a afirmação do status de amunaw ("nobre", "aristocrata") é perpassada por acusações de feitiçaria. Isoladamente, o status de amunaw não garante poder político. Entre os Wauja, é extremamente importante somá-lo ao status de nakai wekeho ("dono" de ritual) (Barcelos Neto 2003, 2004a).

Penso que os dados da etnografia wauja vão ao encontro de uma idéia de Coelho de Souza (2001:388), que sugere a feitiçaria operar como um contraponto à chefia, dito em outras palavras, como um operador dialético do sistema xinguano que lhe permite ser continuamente reconstituído. As acusações, sobretudo as de assassinato, tecem uma urdidura política que traz a feitiçaria para o centro da socialidade wauja. Todos os status sociais wauja expressam, em sua estrutura de ação, marcadores dialógicos que envolvem, 
de modo simultâneo ou sucessivo, a feitiçaria. Uma doença difícil de curar é, do ponto de vista dos xamãs visionário-divinatórios (yakapá), o resultado da ação de um feiticeiro poderoso; uma pessoa preguiçosa, que deliberadamente não quer se envolver na vida ritual, tem chances de ser vista pelos "donos" de ritual (nakai wekeho) como um aprendiz de feitiçaria; uma pessoa que faz fofocas contra os chefes também corre igual risco.

Em seu clássico estudo sobre os Kalapalo, Basso (1973) identifica quatro status sociais: anetaw (amunaw, "nobre", "aristocrata"), oto (nakai wekeho, "dono" de ritual), ifï (kawoká-mona, performer/especialista ritual) e fuati (yatamá, xamã ${ }^{8}$ ). Idealmente, nada impede que um homem wauja ou kalapalo acumule mais de um desses status, contudo, ele poderá encontrar a oposição de pessoas de sua aldeia em relação a esse esforço de acumulação. A alternativa usualmente mais seguida, mas não a mais almejada, é acumular prestígio, no máximo, em dois status diferentes. O acúmulo de status, em especial pelos chefes (amunaw), é uma das estratégias mais comuns para assegurar prestígio político e controlar fluxos de acusações.

Menezes Bastos oferece-nos uma síntese precisa do que vem a ser um amunaw (morerekwat em kamayurá) com um elevado grau de poder político:

O homem eminente xinguara é basicamente o núcleo de uma grande parentela - um sogro/cunhado/irmão conspícuo - e de uma clientela também importante - um cativizador e asilador por excelência. Por outro lado, seu acesso privilegiado ao ritual e ao xamanismo - à legislação, enfim, da etiqueta da xinguanidade — lhe propicia a concentração de poder indispensável para a manutenção do controle que detém sobre o sistema, inclusive sobre suas manifestações em "feitiçaria" (1995:260).

Por outro lado, tal concentração de poder pode torná-lo um chefe altamente temido. A duração e a intensidade dos investimentos que a comunidade faz em um amunaw nem sempre são previsíveis e certos estados de coisas (e.g. adultério, conflitos com afins e descontroles psicológicos do chefe) podem comprometer o seu prestígio e mudar o curso da representação política. Nesse curso incerto, em que grandes chefes podem cair e pequenos "nobres" podem subir, as acusações de feitiçaria têm um papel decisivo. Mesmo um amunaw-iyajo (chefe principal) corre o risco de ser executado. A feitiçaria tem esse duplo caráter: ela pode servir para perseguir, eliminar ou exilar os adversários de um chefe, bem como pode se voltar contra este para destituí-lo ou até mesmo apagar a possibilidade de seus descendentes de produzirem e de potencializarem seu status amunaw. Viveiros de Castro conta que Aritana II, o avô do atual 
chefe Aritana, foi assassinado por um Aweti, envolvendo acusações de feitiçaria (1977:66). O filho de Aritana II, pai do atual Aritana, esperou 19 anos para realizar o Kaumai de seu pai (Ferreira apud Carneiro 1993:410). A realização desse Kaumai - tardio em função da fragilização sofrida após o assassinato e da subseqüente dissolução da aldeia yawalapíti, no final da década de 1930 - coincidiu com a época do realdeamento dos Yawalapíti, em 1948, e contribuiu para recolocar a linha "Aritana" de descendência na alta posição que ela ocupava anteriormente.

Os estudos de Ireland $(1986,1988,1993,1996)$ mostram como antigos chefes wauja conseguiram, por meio de acusações de feitiçaria, exilar ou executar os seus inimigos, todos eles amunaw de menor ou igual status. As acusações de feitiçaria e as execuções podem levar uma linha de amunaw ao desaparecimento, devido à dificuldade que seus membros enfrentam, na condição de exilados, em confirmar e em produzir ritualmente o seu status de amunaw. Se este status não for confirmado a cada geração alternada, a linha corre o risco de extinção. Eis o conflito maior: intimidar/submeter determinadas pessoas que possam comprometer o status e o prestígio político dos amunaw.

\section{Divinação, contrafeitiçaria e predação}

Os feiticeiros têm uma maldade intrínseca que é capaz de atingir, inclusive, pessoas que não são o seu alvo. Feiticeiros podem até não desejar o poder político, mas eles são quase inevitavelmente convertidos em figuras políticas, pois o que eles promovem - a morte - está no limiar de um feito político deliberado, por isso Ireland fala de condição politicamente imputada. Há, portanto, a figura do feiticeiro como um modelo de pessoa (ou antipessoa) e a figura do acusado, ${ }^{9}$ que nem sempre corresponde ao modelo. $\mathrm{O}$ feiticeiro existe, na maior parte das vezes, em uma condição de virtualidade, que apenas se atualiza com a perseguição ou a execução do acusado. Mas uma acusação nua e crua não torna o acusado um feiticeiro, apenas a interpretação do tũpaki, a forma mais poderosa de contrafeitiço, pode dar o veredicto final. Assim, o feiticeiro só é socialmente revelado através de uma condição de violência legalmente perpetrada contra ele. A contrafeitiçaria (tũpaki) justifica todos os atos de perseguição, em sua condição sempre pública e socialmente validada.

O tũpaki é um modo de conhecimento abdutivo operante em uma cadeia temporal em que o feiticeiro passa da condição de agente letal para a de paciente em uma ação letal. Não observei a feitura de um tũpaki. ${ }^{10}$ 
Os dados que obtive foram gerados das conversas sobre um tũpaki que estava em funcionamento na aldeia kamayurá de Ipavu ao longo do ano de 2002. Vejamos o processo.

Esquema: as condições de agente [A] e paciente [P] do feiticeiro através do tempo

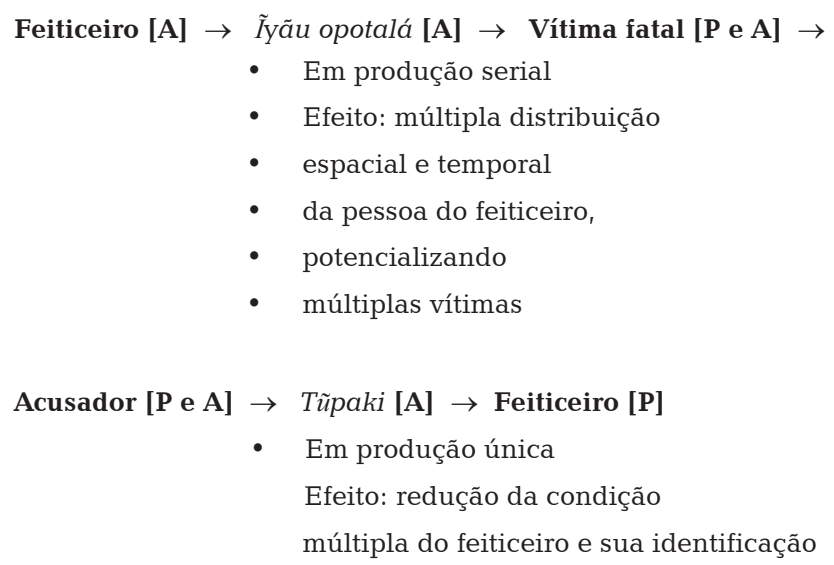

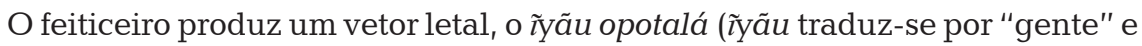
opotalá por "vil"), por meio de sympathetic magic, gerando uma vítima fatal, da qual serão retirados um dedo mínimo e mechas de cabelo que se unirão às matérias orgânicas secretas para formar um z̃yãu opotalapitsi ("boneco", imagem de gente) do feiticeiro, em um processo semelhante à sympathetic magic que gerou o z̃yãu opotalá. O detalhe fundamental é que a relação sympathetic entre o "boneco" e o feiticeiro só é possível em função das palavras (cantos?) secretas entoadas durante o processo de feitura/amarração da "imagem" do feiticeiro. Uma vez pronto o z̃yãu opotalapitsi, ele será alvo dos mais altos cuidados. Seu destino será uma grande panela kamalupo, tipo kurisepu, de paredes altas e bordas extrovertidas e arredondadas, onde o "boneco" passará por um longo processo de cozimento que se espera resultar na morte do feiticeiro. Iyãu opotalá e tũpaki compartilham a característica de serem artefatos letais, porém com as seguintes diferenças: o primeiro é produzido em série e pode matar todos que dele se aproximarem, e o segundo é uma produção singular com o objetivo de matar um determinado feiticeiro.

A panela do contrafeitiço deve ser vigiada dia e noite - pois os feiticeiros farão de tudo para inutilizá-la — e seu fogo e água constantemente mantidos. A panela é colocada no interior da casa onde a vítima morreu, próxima ao local onde dormem as pessoas da casa. É dito pelos Wauja que a panela "trabalha sozinha". É ela que mata o feiticeiro de calor/febre. O feiticeiro entra 
em "combustão" interna e morre seco, com a pele colada nos ossos. Durante a "combustão", o feiticeiro e a panela são um só, pois foram colocados em uma relação de magia por contágio e semelhança (cf. Frazer apud Gell 1998: cap. 7). Se o feiticeiro for muito forte ou se ainda receber a ajuda de outros feiticeiros, a panela poderá "explodir" (rachar). Se isso acontecer, significa que o feiticeiro conseguiu "vencer" o tũpaki, o que coloca os familiares da vítima em especial risco de vida, pois o feiticeiro, livre do tũpaki, poderá rapidamente se voltar contra todos eles. Daí uma atitude mais radical deve ser tomada em segurança dessas potenciais vítimas.

Em virtude do risco de "explosão" da panela, o tũpaki mostra-se muito mais como um dispositivo de intimidação dos suspeitos de feitiçaria do que uma arma letal em si mesma. O desejo do(s) acusador(es) é que o tũpaki mate o feiticeiro, para que ninguém tenha que se "sujar" com o seu sangue. O tũpaki é um esforço de reversão do poder letal do feiticeiro contra ele próprio. Por esses motivos, o tũpaki é a forma sancionada pela etiqueta e pelo resguardo da pureza. Quem se "suja" dessa forma deve passar por uma longa limpeza com ervas e eméticos, cujos resultados nem sempre são satisfatórios.

Assim como o ryãu opotalá, o tũpaki também funciona segundo um regime de atuação espacialmente limitado. Portanto, quando um tũpaki começa a "trabalhar", é comum, dizem os Wauja, o feiticeiro fugir (exilar-se) da aldeia a fim de evitar a sua "combustão". À distância ele poderá ensaiar uma neutralização do tũpaki. Os parentes da vítima que estão cuidando da panela ficam vigilantes, pois mesmo em seu exílio o suposto feiticeiro pode agir com o auxílio de "roupas" (onaĩ), vestimentas-corpos capazes de transformá-lo em animais, as quais lhe permitiriam viajar até a sua aldeia natal, "disfarçado" em algum pássaro ou animal terrestre. O artifício do "disfarce" é muito antigo, remontando ao tempo de Kamo (Sol) e Kejo (Lua), que usaram "roupas" para roubar a mandioca e as flautas Kawoká dos povos-porco (Autupoho).

Segundo os Wauja, nem todos os xamãs visionário-divinatórios (yakapá) conseguem revelar a identidade dos feiticeiros e, mesmo que o façam, é necessário o tũpaki para que a mesma seja confirmada. O tũpaki de Ipavu teria revelado a identidade do suposto feiticeiro. Anteriormente acusado e ameaçado de morte, o suposto feiticeiro, por evitar a todo custo saídas da casa, passou a defecar em seu interior. Seu medo, efeito psicológico do tũpaki, entre outras coisas, foi interpretado como uma "confissão". O acusado foi assassinado a tiros de revólver no interior de sua casa.

Os Wauja dizem que esse Kamayurá de Ipavu "não era feiticeiro" e nem os seus parentes anteriormente executados nessa mesma aldeia. Os parentes wauja do suposto feiticeiro defendem que ele foi morto por pura maldade dos 
seus algozes. A execução de um suposto feiticeiro é, de longe, o assunto mais polêmico no Alto Xingu. Embora eu tivesse apenas dois colaboradores que se dispunham a discutir o assunto, ambos deram-me a impressão de que os Wauja duvidam que se possa precisar, com absoluta certeza, a identidade de um feiticeiro, seja por meio da divinação xamânica (transes e/ou sonhos) ou do tũpaki. Os Wauja não questionam a existência da feitiçaria, mas isso não quer dizer que eles estejam dispostos a personificá-la todo o tempo, e muito menos a acionar os dispositivos de perseguição e execução que ela permite.

Feiticeiros não são para se matar, são para se ter medo, diz a reflexão de um sábio wauja. O medo como um valor da incerteza e vice-versa. No sentido desse argumento, vale observar que os yakapá revelam, com relativa facilidade, as identidades dos apapaatai que estão causando doenças. No entanto, essa revelação é uma parte primordial da terapêutica. Já a ação de tais e tais feiticeiros é muito raramente revelada pelos yakapá, embora seja dito que eles são capazes de os descobrir. Os yakapá não os revelam abertamente por não saberem, mas por temerem gerar conflitos entre os acusados e as famílias dos acusadores. Sua certeza específica deve ser ocultada para dar lugar a uma incerteza mais ou menos geral, cuja vantagem é uma segurança também mais ou menos geral. A feitiçaria paira, sua densidade não pode ser precipitada sem fortes razões. A estratégia é mantê-la relativamente em suspenso, o que gera um estado latente de tensão. Trazê-la à tona pode resultar em inevitáveis desastres.

O que os Wauja fazem é usar a feitiçaria como um dispositivo para negociarem imagens pessoais e de grupos familiares. O valor sociológico deste dispositivo é menos evidente em situações do cotidiano do que em momentos de crise profunda como, por exemplo, por ocasião da morte súbita e/ou dolorosa de alguém. Quando isso ocorre, julga-se imediatamente que há um ou mais feiticeiros colocando em risco a vida dos membros do grupo. Nesse momento, a feitiçaria torna-se uma questão eminentemente pública. Porém, o que a fundamenta como experiência social é a acusação.

Um acúmulo de acusações tende a cristalizar em alguém uma imagem de feiticeiro. Escândalos envolvendo adultérios e recorrentes reações agressivas concorrem para gerar acusações de feitiçaria. A execução do acusado é vista como um modo de suspensão do risco público. Contudo, a passagem da acusação à execução é bastante complexa. Em geral, um acusado é alguém que se envolve intensamente em conflitos comuns de vários tipos: desde brigas ligadas a adultérios até uma inimizade pessoal relacionada ao reconhecimento público de status políticos específicos. Ireland (1988), ao questionar sobre a natureza das execuções, notou que um inimigo privado só pode ser executado, sem sérias e imediatas retaliações contra o matador e/ou o seu mandante, se ele for con- 
siderado uma ameaça pública. Portanto, não há como desvincular a acusação de processos privados e públicos simultaneamente construídos. Quando uma acusação torna-se pública, o problema já não é tanto a feitiçaria como modelo, mas a acusação como perseguição e vingança, como violência sancionada.

Volto novamente para a condição de "virtualidade" da feitiçaria e para as suas implicações no entendimento da noção xinguana de pessoa. Antes de tudo, o feiticeiro encarna uma imagem de ambigüidade: nem totalmente "igual" e "próximo", nem totalmente "diferente" e "distante", identificável e não-identificável. Exploremos a idéia de que o feiticeiro é um modelo de antipessoa humana, na medida em que ele expõe, segundo os valores Wauja, a face mais brutal da violência: a morte.

No Alto Xingu, a violência está deslocada para o pólo da não-humanidade, pois xinguanos "de verdade" são pacíficos. Assim, se uma mulher vir as flautas Kawoká e for estuprada em decorrência disso, é dito que foi Kawoká que a estuprou - a violência é uma perspectiva deslocada para fora do campo da intencionalidade humana. Certamente, quando alguém morre de maneira dolorosa, a ambigüidade da condição humana toma contornos mais nítidos e revela um lado nefasto, pois idealmente é suposto que apenas os animais e os monstros sobrenaturais "matem" os humanos. Dentre as idéias centrais da filosofia xamânica wauja vigora aquela que afirma a existência de múltiplas entidades não-humanas (basicamente seres mascarados em formas monstruosas e/ou animais) dotadas de intenções e de pontos de vista próprios. Essas entidades, denominadas apapaatai, estão na origem da doença e da cura, mas não da morte.

De um modo sumário, os apapaatai podem ser considerados os seres prototípicos da alteridade. Uma alteridade que se expressa por meio de transformações múltiplas e desiguais que podem definir os apapaatai como animais, monstros, "bichos", artefatos, "espíritos", fenômenos atmosféricos e astronômicos, heróis culturais e/ou xamãs; essas mesmas transformações abrangem, em contextos patogênicos e rituais, os próprios Wauja (Barcelos Neto 2006). Por "transformações múltiplas e desiguais" refiro-me às transformações da natureza dos seres, sejam elas nos domínios dos seus corpos, "roupas", afetos, intenções, capacidades e/ou perspectivas. As identidades dos seres estão diretamente ligadas ao modo como esses domínios se organizam e se apresentam no curso das relações que os seres empreendem no mundo. O aspecto mais importante de tais relações é que a maioria dos apapaatai pode ser convertida da posição de agentes patogênicos à posição de personagens (artefatos) rituais (Barcelos Neto 2004a, 2004b), os quais devem incorporar padrões de beleza, cujos efeitos incidem diretamente sobre a cura do doente grave (vide discussão na seção seguinte). 
A guerra e a caça são as expressões "típicas" da predação na Amazônia indígena. Em comparação a povos do noroeste amazônico (Århem 1996; Silverwood-Cope 1990) e os Tupi (Fausto 2001; Lima 1996; Viveiros de Castro 1986), a cosmologia da caça é pouquíssimo elaborada entre os xinguanos. Onde se situaria então o locus central da predação wauja? Ao que indicam meus dados, a "lógica canibal" (Fausto 2001:533-546) xinguana centra-se nas doenças graves de apapaatai que correspondem a um modo de predação distinto da feitiçaria e da guerra, nas quais a vítima é aniquilada. Se o resultado da ação patogênica dos apapaatai é a apreensão das subjetividades humanas, o da feitiçaria é o assassinato, que cancela qualquer tipo de troca e gera retaliações e prolongados conflitos entre famílias. A predação entre os Wauja apresenta-se como uma dobradura com uma face exterior, povoada por alteridades sobrenaturais patogênicas, e uma face interior, povoada por feiticeiros letais. Essa dobra predatória forma uma imagem contínuo-gradativa do rapto de alma à morte definitiva.

\section{A antiarte dos objetos patogênicos}

O feiticeiro representa um modelo de não-humanidade. Talvez ele seja uma de suas imagens mais bem definidas. Feiticeiros, não-feiticeiros e apapaatai configuram, no âmbito da agência patológica, padrões relacionais que permitem um outro ponto de vista para a comparação entre as noções wauja de humanidade e não-humanidade. A relação entre os dois primeiros é antagônica; entre os primeiros e os últimos pode ser, em alguns casos, de troca; e entre os dois últimos é uma relação mais complexa que se desenvolve de uma agressão (i.e. rapto da alma como doença grave) para uma aliança (i.e. oferta ritual de alimentos para os apapaatai e conseqüente proteção destes contra novas doenças).

Se imaginarmos os não-feiticeiros no centro de uma condição ideal de humanidade, temos os apapaatai muito mais próximos destes do que os feiticeiros. Os apapaatai estão sociologicamente mais próximos dos não-feiticeiros porque eles são passíveis de serem "domesticados". Já feiticeiros não se "domesticam", ou se matam ou se expulsam da aldeia. Por participarem de experiências positivas de construção sociocósmica — rituais de máscaras e aerofones e auxílios aos xamãs, por exemplo — os apapaatai são capazes de assumir uma posição produtiva no sistema de relação entre humanos e não-humanos. Os feiticeiros estão totalmente fora do mundo de reciprocidade (ainda que forçada) que as doenças graves de apapaatai instauram. A sociabilidade dos feiticeiros é sempre negativa, porque ela mata, impe- 
dindo qualquer fluxo de contrapartidas. Com os feiticeiros não se negocia, eles não querem nada em troca, pois eles agem contra a comunidade. Este é o grande divisor ontológico entre os feiticeiros e os apapaatai. Embora ambos se expressem por meio da dor, seus fins são profundamente distintos: o apapaatai quer aliança, o feiticeiro, apenas morte e destruição. Segundo um importante yakapá wauja, os apapaatai não são maus, eles adoecem alguém para depois ajudarem na sua cura e logo ficarem "companheiros" dele (okawokála).

Toda doença tem seu início em um estado decorrente de um desejo alimentar não satisfeito de imediato, conhecido por witssixuki. Embora de modo raro, o desejo ardente e insatisfeito de ter relações sexuais também pode causar wĩtsixuki, pois o sexo é uma forma alimentar de relação. O wĩtsixuki não é um estado corporal, e nem tem uma ligação direta com a fome (yumanakuki), esta sim um estado corporal. Trata-se de um estado da alma que nos fala primordialmente sobre o descontrole dos desejos. O witsixuki produz, aos olhos dos apapaatai, a condição única para o rapto de frações da alma humana. Em companhia dos apapaatai, a alma passará a se alimentar das comidas dos "bichos" e, com o passar do tempo, se tornará um deles.

A fenomenologia da doença e da morte distingue a natureza e a potência dos feitiços não-humanos e humanos - muitas vezes o primeiro tipo de feitiço funciona como um facilitador da ação de feiticeiros. No momento em que uma pessoa acaba de entrar em estado de witsixu e sofre o primeiro rapto de sua alma, a doença está em um estágio bastante inicial e pode ser rapidamente curada pelos xamãs. Mas se o doente não apresentar melhora após o esgotamento de todo o repertório terapêutico xamânico, os principais responsáveis pela doença não serão mais considerados os apapaatai, que talvez até já tenham saído da cena patológica depois de tanta intervenção xamânica. A conclusão de que algo mais perigoso atua sobre o corpo do doente depende de um agravamento abrupto da doença ou de um estranho prolongamento desta. O enfraquecimento inicial do doente, causado pela introdução das flechinhas de apapaatai, é considerado uma ótima oportunidade para que um feiticeiro lhe prepare um feitiço letal.

O poder mortal dos feitiços feitos por humanos (ixana) reside unicamente em suas características físicas. Eles são sempre externos aos corpos de seus artífices, são artefatos. O que é bem diferente dos feitiços de apapaatai, que são emanados do seu próprio corpo ou são miniaturas deste que se propagam por meio de roupas (naî). Os feitiços feitos pelos humanos são artefatos dotados de intenção. Depois de fabricados, eles agem "sozinhos", eles são "automáticos", como dizem os Wauja. Uma vez instalado no interior do corpo de alguém, é o feitiço que "comanda" a dor, ele assume uma 
independência em relação ao seu artífice, que já não precisará se dedicar à manutenção do feitiço.

Ao contrário do ixana, as flechinhas de apapaatai não são letais. Elas são moles e muito pequenas e, quando penetram no corpo, permanecem no nível da epiderme e "não são difíceis de tirar", conforme explica Ulepe, um importante yakapá wauja. Mas as flechinhas multiplicam-se rapidamente pelo interior do corpo: um pedaço parte-se em dois, e assim vão aumentando em proporção geométrica até atingirem outras partes do corpo, para as quais elas migrariam. Daí porque os xamãs wauja fazem sucessivas sessões para sugar as flechinhas até que mais nada reste, pois se algo sobra, mesmo que seja um pouquinho, a dor pode voltar. Os ixana, por sua vez, são feitiços duros que penetram fundo no corpo, sendo portanto difíceis de serem extraídos por sucção. Eles se alojam em partes vitais, como o coração, o pulmão e o cérebro. São feitos para matar.

O feiticeiro wauja é um artífice de artefatos letais. É um especialista de uma "prática" da qual apenas se vêem os seus efeitos e nunca a ação propriamente dita. A ação do feiticeiro só existe como efeito, sendo passível de ser revelada unicamente pelos xamãs que ou extraem os feitiços do corpo da vítima ou os localizam escondidos nos locais de trânsito (roças, margens de lagoas e rios, caminhos e banheiros). Disse-me um colaborador que "o feitiço pode estar bem na sua frente, no caminho que você toma todo dia para a roça, para o rio, mas você não consegue ver, só pajé consegue". O feitiço é, portanto, uma "descoberta" do xamã. Ele é, em sua qualidade artefatual, da forma como é apresentado aos espectadores de uma sessão de divinação, o único índice explicativo para o estado moribundo de um doente grave.

Nenhum xamã sai à procura de feitiços, a menos que todas as possibilidades de extração de flechinhas de apapaatai e outras práticas terapêuticas relacionadas a estes tenham se esgotado. A divinação do(s) local(is) onde os feitiços são escondidos é a última das alternativas em um processo terapêutico. Como "invenção" etiológica, o feitiço é um domínio exclusivo do xamã, o qual oferece aos não-xamãs o acesso visual aos objetos patológicos. Estes surgem muitas vezes configurados por bonequinhas (ou na variante de pequeninas trouxas) de folhas amarradas a pedaços de beiju, fios de cabelo, linhas de buriti ou de algodão e excrementos, chamadas de r̃yãu opotalá. Segundo os Wauja, este artefato letal dá forma antropomorfa e agentiva aos mais baixos valores morais.

O ̃̃yãu opotalá é o mais poderoso tipo de feitiço. Além de matar, ele pode ser feito para atrair nuvens de gafanhotos e ataques de formigas tocandira, contaminar alimentos, impedir o crescimento dos tubérculos, causar epidemias de diarréia etc. O feiticeiro tem a capacidade de trabalhar contra o grupo como um todo. 
Os feitiços do tipo ĩyãu opotalá são figuras antropomorfas ou zoomorfas em miniatura. Uma vez desfiguradas, sua eficácia fica comprometida, mas esta só é completamente eliminada se os materiais que constituem o ĩyãu opotalá forem mergulhados em recipientes com água fria. As figuras não representam a pessoa a quem se deseja fazer o mal, portanto, não é uma relação de semelhança com a vítima o que caracteriza o ĩyãu opotalá, e sim o uso de restos orgânicos da vítima para a fabricação da imagem. A semelhança postulada nesse tipo de feitiço é substancial e não visual.

Uma vez constituído, o r̃yãu opotalá já é alguma coisa (ou alguém) capaz de atuação e interação próprias, não sendo ele um meio para se atingir algo e nem estando no lugar de algo. O ĩyãu opotalá é a extensão material de uma intenção que pode ser espalhada por tantos lugares quanto seu artífice desejar. A metáfora básica que esse tipo de feitiço evoca é a da dispersão espacial da pessoa do feiticeiro. Trata-se da sua distribuição em "outras pessoas", que ele é capaz de produzir e espalhar.

Vejamos um exemplo que os Wauja dizem ser recorrente. Um feiticeiro pode fazer pequenas imagens de porcos com o objetivo de destruir a roça de alguém. Essas imagens de porcos irão interagir com porcos animais, chamá-los em varas muito grandes, despertar sua voracidade para que eles consigam saltar ou destruir as cercas que protegem as roças. O ̃̃yãu opotalá realiza negócios vários - e.g. tornar os tubérculos de mandioca raquíticos, apodrecer as frutas, trazer nuvens de insetos - porque ele é capaz de interagir

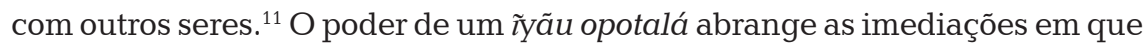
ele se encontra fisicamente, seu poder não é portanto metafísico ou místico. Como nota Gell, num trecho em que ele comenta o erro de Frazer em pensar a física indígena como "confused" ou "non-standard", a magia:

é aquilo que se tem quando se dispensa uma teoria física em vista de sua redundância, e quando se busca apoio na idéia, em si mesma perfeitamente praticável, de que a explicação de qualquer evento (especialmente se este é socialmente saliente) é que ele é causado intencionalmente (Gell 1998:101).

Em fevereiro de 2000, no início de minha segunda viagem a Piyulaga, fui informado de que "estava faltando peixe na aldeia". Até o dia 2 de abril, quando parti em viagem de volta para a cidade de Canarana (Mato Grosso), tal escassez ainda se prolongava. Mas não era só peixe que faltava: mandioca também. O estoque acumulado na estação seca (junho a setembro) anterior não conseguiu supri-los de amido ao longo da estação chuvosa (novembro a março). Esse estado de dupla escassez era visto como algo excepcional para ter uma causa não-intencional. Disseram-me que os tubérculos não 
se desenvolveram o suficiente e que um $\tilde{y} \tilde{a} u$ opotalá tinha sido colocado na lagoa Piyulaga para espantar os peixes. Indaguei por que alguém faria tal tipo de feitiço, visto que ele seria igualmente prejudicado. A resposta que obtive das pessoas era como uma frase de efeito, pronta para qualquer pergunta que envolvesse alta feitiçaria: "esse feiticeiro quer acabar com a aldeia". Era dita quase em tom de consenso. Enfim, supunha-se que a intenção do feiticeiro era dispersar os Wauja pelo seu território em busca de alimento, pois ele já tinha tornado a vida na aldeia bastante difícil. Em resposta a essa situação, um dos chefes partiu, em meados de março, para uma área cultivada ao sul de Piyulaga, levando com ele quase toda a sua família. Sua atitude repercutiu como se ele estivesse literalmente dizendo que o plano do feiticeiro estava de fato funcionando e que ele era o primeiro a ser obrigado a sair da aldeia devido à falta de comida. Assim, além de resolver o seu problema alimentar, ele estava reiterando o modelo que considera a feitiçaria uma ação destrutiva do socius.

A escassez de alimentos levou algumas crianças a estados de desnutrição, dentre as quais três ficaram muito doentes. Imaginem-se os inúmeros estados de wĩtsixuki que tal escassez teria provocado, facilitando a aproximação patogênica dos apapaatai. É claro que o wĩtsixuki não é diretamente causado pela fome, como vimos acima, mas quando alguém está com fome sua atenção sobre alimentos é de fato bem maior do que quando não tem fome. Para o único caso crônico de doença — que resultou em morte — diagnosticou-se a ação simultânea de apapaatai (especificamente o apapaatai "dono" do peixe ukixá-kumã) e daquele r̃yãu opotalá que estava escondido na lagoa Piyulaga para espantar os peixes. Embora estivesse em um local distante da vítima, o z̃yãu opotalá estava deixando a criança "como um peixe fora d'água", "respirava, mas não tinha ar para ela". Como a criança não apresentava melhora da sua pneumonia, levaram-na para o Posto Leonardo, onde ela aparentemente recobrou sua saúde pois, conforme seu avô, ela já estava longe do local de abrangência daquele ĩyãu opotalá. Assim, com as forças recuperadas, a criança já poderia voltar para Piyulaga. Mas algo inesperado veio a acontecer no Leonardo: a criança morreu subitamente no colo da mãe, na sala de espera da enfermaria. Houve múltiplos agentes envolvidos na sua morte: o "dono" do ukixá-kumã (pois seu pai, que estava em Canarana, tinha comido desse peixe considerado kanupá, i.e., tabu); o iwejekui ("alma do morto") de uma mulher kuikuro, que tinha morrido anos antes naquele mesmo local, estava gostando da criança e, por isso, queria a sua alma como companhia (uma parte dela pelo menos, ou mais possivelmente o seu iwejekui); por fim, um outro z̃yãu opotalá que estava escondido nas imediações do Posto. 
Em 2 de abril de 2000, acompanhei Itsautaku na busca desse feitiço que tinha contribuído para a morte do bebê wauja no Posto Leonardo. Entretanto, o feitiço tinha sido feito para a tal mulher kuikuro que também morrera na enfermaria. Dois xamãs kuikuro foram ao Leonardo a fim de localizar o feitiço e neutralizá-lo. Porém, segundo Itsautaku, os seus esforços foram em vão, pois eles teriam descoberto apenas o feitiço "de mentira", o qual é geralmente feito pelos feiticeiros com o objetivo de enganar os xamãs de pouca habilidade divinatória. Itsautaku apostava que o feitiço "verdadeiro" ainda permanecia atuante nas proximidades do Posto, devido à recente morte do bebê, ou seja, o feitiço não tinha sido descoberto pelos "incompetentes" xamãs kuikuro, nem teria sido removido para outro local pelo seu autor. Como a criança que morreu era wauja, Itsautaku resolveu então localizar o feitiço, o qual pude ver após uma sessão divinatória em que Itsautaku intoxicou-se de tabaco, seguiu correndo de olhos fechados em direção ao mato de lá trazendo o ryãu opotalá, feito por um incógnito feiticeiro kuikuro. Depois de ter recobrado os sentidos, Itsautaku providenciou desembrulhar o feitiço, de aparência e textura de um coprólito, que se esfarelou em meio aos fios de cabelo e aos outros materiais que o enrolavam.

Os xamãs têm uma posição sempre $a$ posteriori em relação ao feitiço, e os feiticeiros uma posição tanto a priori quanto a posteriori, ou seja, estes últimos fazem e desfazem feitiços, enquanto os primeiros apenas os desfazem, ou melhor, desembrulham. É da relação entre as duas posições que emerge uma parte importante dos discursos explicativos sobre morte e identidade pessoal. Relatarei um caso que torna mais explícita a relação entre um xamã em ofício e um suposto feiticeiro.

No início da década de 1980, uma velha chefe (amuluneju) wauja sofreu durante semanas de fortes dores em função de uma flecha de feiticeiro que estava dentro do seu corpo. Várias sessões de xamanismo foram feitas em seu benefício, contudo elas aliviaram muito pouco as suas dores, fazendo sua morte parecer iminente. Um de seus filhos, desesperado, fez acusações em praça pública, ameaçando de morte os acusados caso eles não suspendessem o efeito do feitiço. No prazo de poucos dias, a velha amuluneju começou a sentir-se melhor e sua morte, que era iminente, veio a ocorrer apenas alguns anos mais tarde. Um suposto e incógnito feiticeiro não somente gera um processo de morte, como também pode interrompê-lo, caso sinta-se intimidado pelos xamãs visionário-divinatórios e/ou pelos familiares da vítima. É apenas o feiticeiro que tem domínio sobre todo o processo, não o xamã — este só desembrulha os feitiços, já o feiticeiro pode tanto embrulhá-los (amarrá-los) quanto desembrulhá-los.

Menezes Bastos $(1990,1995)$ sugere que no Alto Xingu os conflitos, em suas diferentes variações, são mediados por padrões de aceitabilidades estético-mo- 
rais e que o xamanismo e a feitiçaria configuram — juntamente com expressões padronizadas como a música, a dança e o grafismo - um "sistema artístico".

Mencionei acima algumas concepções estéticas que envolvem a figura dos feiticeiros (baixa estatura, "fala feia", ou seja, propensão a fofocar, musculatura pouco desenvolvida, abdômen saliente). Mas é talvez a sua arte de produzir objetos patogênicos, letais e anti-sociais, mais do que as suas características físicas, que coloca os feiticeiros no pólo da fealdade. Não será possível analisar aqui os diferentes modos com que a arte wauja lida com a sua própria noção de fealdade. ${ }^{12}$ Todavia, no caso da presente discussão, é plausível supor que um desses modos pode ser lido pela chave do colapso da pessoa: a morte. O ethos da feitiçaria e seus produtos (e.g. kuretsi, ixana, ryãu opotalá) teriam, portanto, um sentido paradigmático para aquilo que poderíamos chamar de anti-arte wauja.

Os comportamentos sociais e as expressões plásticas caracterizadas como feias apontam para uma condição moral opotalá (vil), devendo ser "marginalizadas" das experiências estéticas relevantes para a sociabilidade wauja. A beleza tem um lugar bem distante da feitiçaria no baralho conceitual wauja. Mas do ponto de vista prático, as expressões de beleza (o canto xamânico, as palavras da reza, o desenho simétrico e límpido no corpo do dançarino, as máscaras e as flautas perfeitamente confeccionadas, o pagamento ritual feito com esmero) são meios que tentam revelar e anular a feitiçaria. Por um princípio ontológico, a beleza é tudo aquilo que não é feitiçaria. A beleza é um paradigma do universo terapêutico ${ }^{13}$, este propriamente um contramodelo da feitiçaria.

Enfim, a idéia defendida aqui é a de que grande parte daquilo que denomino arte wauja reveste-se de puro valor terapêutico, sendo sua ação caracterizada como cosmética na medida em que ela é capaz de reordenar/ equilibrar as relações entre diferentes domínios do cosmo. E os objetos rituais têm um protagonismo nessa cosmética, pois eles são o ponto de convergência de duas noções cruciais do pensamento wauja: beleza (awojotopapai) e alegria (kotepemonapai). A beleza é o substrato essencial para a produção da alegria - estado imprescindível para a obtenção do sucesso terapêutico em caso de doenças graves ("morte"). Após a divinação, o papel terapêutico do yakapá torna-se secundário, sendo a terapia então formalmente assumida por especialistas rituais (kawoká-mona).

O ideal wauja de beleza ${ }^{14}$ impregna quase tudo o que faz parte do campo ritual, mas ele começa no corpo de sujeitos específicos, com a pintura corporal ou a dos artefatos. Ao serem indagados sobre o porquê da pintura, os Wauja não oferecem muito mais do que lacônicas respostas do tipo: "é pra ficar bonito". E por que tem que ficar bonito? — "para ficar alegre", respondem. Antes 
de iniciarem qualquer atuação ritual, os Wauja devem estar minimamente pintados e adornados, pois é inconcebível que alguém dance sem qualquer marca visual sobre o corpo. Um indivíduo pode até dançar sem certos adornos plumários, ou com adornos estragados, mas isso o deixaria envergonhado, o que depende, obviamente, do ritual do qual ele toma parte.

Em um ritual de apapaatai, os Wauja alegram-se para os apapaatai; a alegria "domestica" sua monstruosidade, neutraliza (ou pelo menos minimiza) a sua potência patogênica sobre os humanos. A "apatia" e a "brabeza" são o oposto dessa alegria, sentimentos de quem detesta festas - matanaká - feiticeiros e gente preguiçosa que não gosta de trabalhar para alimentar os performers rituais. A alegria começa com a beleza, porém ela não termina aí: fartura de comida, música e dança articulam-se mutuamente.

No mundo xinguano, a obtenção e a oferta de objetos belos são sinais de enobrecimento tanto de quem oferece quanto de quem recebe. Os Wauja levam extremamente a sério essa proposição, a ponto de lançarem coisas "feias" para o campo conceitual da feitiçaria, ela mesma o veículo da dor, da morte e da tristeza, sentimentos opostos àqueles que devem ser produzidos pelos rituais. Os Wauja fazem muita questão de enfatizar que seus objetos de uso cotidiano, recebidos como pagamento ritual, foram "belos" um dia. Como se pode facilmente notar, passado algum tempo de uso, a fuligem apaga por completo a pintura das panelas; a poeira e a terra impregnam os cestos; as pinturas das pás de beiju e desenterradores de mandioca descascam, dando a impressão de que esses objetos nunca foram pintados. Porém, a sua beleza pretérita fica registrada na memória de quem ofereceu e de quem recebeu. Sim, a beleza também está ligada ao ato. Ninguém está preocupado em conservar os objetos rituais porque eles são belos, e sim em repetir essa beleza em uma produção contínua de objetos e marcar o mundo com alegria.

Recebido em 15 de junho de 2005

Aprovado em 20 de junho de 2006

Aristóteles Barcelos Neto é Pesquisador de Pós-Doutorado no Departamento de Antropologia da USP. E-mail: <apapatai@usp.br> 


\section{Notas}

- O presente texto baseia-se no terceiro capítulo da minha tese de doutorado (Barcelos Neto no prelo). Meus trabalhos de campo foram financiados pelo Governo do Estado da Bahia e pelo Funpesquisa/ UFSC (ano de 1998), pelo Museu Nacional de Etnologia de Portugal (ano 2000) e pela FAPESP (anos de 2001, 2002 e 2004). A CAPES e a FAPESP concederam-me bolsas de estudos em diferentes etapas da pesquisa. Quero registrar minha gratidão aos Wauja e a Bruna Franchetto, Carlos Fausto, Eduardo Viveiros de Castro, Lux Vidal, Maria Rosário Borges, Michael Heckenberger, Pedro Agostinho e Rafael Bastos pelos comentários e incentivos à minha pesquisa no Alto Xingu.

${ }^{1}$ O leitor encontrará na literatura etnológica o termo "Waurá", que é o etnônimo difundido desde a primeira publicação sobre o Alto Xingu (Steinen 1886). Optei grafar "Wauja" por este ser o etnônimo auto-atribuído. Os Wauja são um povo de língua arawak que, há mais de um século, habita as proximidades da margem direita do baixo rio Batovi, na região ocidental da bacia dos formadores do rio Xingu, estado do Mato Grosso, Brasil Central. No entanto, a história dos Wauja no Alto Xingu é bem mais antiga; pesquisas arqueológicas recentes apontam a chegada dos seus ancestrais à região por volta do século IX d.C. (Heckenberger 2001). Desde o século XVIII teve início nessa região a formação de um sistema social multiétnico que integra, além dos Wauja, outros nove grupos de diferentes filiações lingüísticas - Mehinako e Yawalapíti (Arawak); Kuikuro, Kalapalo, Matipu e Nahukwá (Carib); Kamayurá (Tupi-Guarani), Aweti (Tupi) e Trumai (de língua isolada). Os Wauja somam uma população de aproximadamente 360 pessoas, das quais 315 residem em uma aldeia circular com o sistema de praça central e casa das flautas.

${ }^{2}$ Obviamente não se perseguem os apapaatai, pois eles não adoecem ninguém com intenções letais.

${ }^{3} \mathrm{O}$ yutši yawalapíti corresponde ao yalawo wauja, uma substância que os apapaatai-auxiliares do xamã lhe oferecem para que ele ministre curas.

${ }^{4}$ Essa potência é atualizável, como se pode historicamente comprovar. Menget (1985:134) cita o caso de um convite dos Kalapalo aos Yaruma (grupo carib lingüisticamente próximo dos Ikpeng) para participarem de um ritual que, na verdade, era um plano de extermínio dos homens Yaruma e de rapto de mulheres e crianças. A chacina dos Yaruma consumou-se, porém os Suyá, vigilantes de toda a movimentação, foram mais rápidos que os Kalapalo e lograram o rapto.

${ }^{5}$ Nesse panorama etnográfico tão variado, um interessante exemplo é do ritual xamanístico Jeroky, sobre o qual Montardo (2001:10) faz as seguintes observações: "Os Nhandeva afirmam que os Kaiová fazem jeroky como exército, mas eles os Nhandeva, não. O mesmo ouvi entre os Kaiová". O objetivo do ritual Jeroky é tornar seus participantes "belos guerreiros", para que eles possam enfrentar os desafios 
impostos para a continuidade e o equilíbrio do cosmo (Montardo 2002). O ritual aqui é visto como guerra.

${ }^{6}$ Compare-se, por exemplo, a produtividade política das noções wauja de $m u$ sixapai e ukitsapai com os dados ikpeng de Rodgers: "O fluxo negativo e oculto de inveja, ressentimento e raiva dos outros tem uma dimensão sociopolítica altamente positiva, embora não explicitada pelos Ikpeng [por sua vez explicitada pelos Wauja]: sua constante ameaça inibe a acumulação e mantém o fluxo e a redistribuição de recursos mais ou menos equilibrados em uma população que evita tanto a coerção quanto o conflito interno, que seriam ipso facto já externos: cisões" (2002:93). Embora inveja e raiva façam parte das moralidades políticas ikpeng e wauja, seus sentidos operatórios são diferentes. Entre os Wauja, inveja e raiva não são inibidores, ao contrário, são eixos moventes da sociabilidade, propiciam conflitos, geram cisões, contestações.

${ }^{7}$ A noção wauja de inveja-ciúme talvez evidencie uma percepção da distribuição desequilibrada de bens materiais e imateriais. Sempre que eu realizava um pagamento mais substancial a algum colaborador, este me pedia para não divulgar: queria evitar a inveja-ciúme dos feiticeiros, dos fofoqueiros e dos que não gostavam dele. Para os Wauja, os feiticeiros pensam que se eles não podem usufruir o que é dos outros, que os outros também sejam privados de usufruir seus bens, sejam estes artefatos ou o bem-querer de alguém.

${ }^{8}$ Yatamá é apenas o termo genérico para xamã. Há três tipos de especialistas xamânicos entre os wauja: o yakapá (especialista em recuperar almas humanas e localizar e neutralizar feitiços letais), o principal deles, o pukaiwekeho (especialista nas músicas do ritual terapêutico Pukay) e o yatamá (que apenas sabe aliviar dores com o uso da fumaça do tabaco, técnica também conhecida pelos dois anteriores). Há outros dois especialistas terapêuticos, mas que não são reconhecidos como xamãs pelos Wauja, o ajatapewekeho (especialista em plantas medicinais) e o ejekekiwekeho (especialista em rezas).

${ }^{9}$ Para efeitos práticos de acusação ou execução, um feiticeiro é definido contextualmente ao longo de uma série intrincada de fatos que beiram a impossibilidade de ser levantada e de vários processos biográficos, que incluem seus ascendentes, sobre os quais não disponho de um número suficiente de casos para aprofundar a análise. De qualquer modo, quem é hoje acusado pode amanhã estar em uma posição privilegiada, sendo capaz de anular o peso negativo de uma acusação e de ocupar uma posição de acusador. Tornar-se um grande xamã visionário-divinatório é, por exemplo, o melhor caminho para evitar acusações. Não disponho de material suficiente para explorar contextualmente os fluxos de acusações de feitiçaria que conduzem à execução de alguém. Para tanto seriam necessários dados precisos e extensivos sobre perseguições, exílios e execuções documentados segundo um recorte diacrônico de pelo menos um século.

${ }^{10}$ Os Wauja afirmam que apenas os Aweti conhecem toda a cadeia operatória do tũpaki - a principal modalidade de contrafetiçaria que demanda o conhecimento de 
uma série de cantos e de técnicas de fabricação dos "bonecos" de contrafeitiço — sendo por isso considerados imprescindíveis no processo de divinação e perseguição a feiticeiros. Tal reconhecimento parece ter ressonância entre os Kuikuro que, segundo Heckenberger (1999:138; comunicação pessoal), recorreram aos Aweti para colocar em funcionamento a cadeia operatória do tũpaki (kune em kuikuro) por ocasião de uma importante divinação que envolveu a morte de um Kuikuro "nobre" (anetaw).

${ }^{11}$ As formas como os ĩyãu opotalá interferem nos negócios humanos é mais complexa do que a descrição que realizo. Desconheço todas as variáveis de sua atuação, visto que é muito difícil abordar o assunto isoladamente entre os Wauja. Quem demonstra muito conhecimento sobre feitiços é obviamente um feiticeiro, portanto, ninguém se sente à vontade para dar informações detalhadas sobre como são feitos os feitiços e como eles agem dentro e fora do corpo. Por isso, uma boa parte das informações que possuo sobre feitiçaria foi coletada em locais distantes da aldeia wauja onde os informantes sentiam-se seguros para discutir o assunto.

${ }^{12}$ Vide Barcelos Neto (2002, 2004b, 2004c) para uma discussão aprofundada sobre arte e estética wauja.

${ }^{13}$ Sobre "terapias estéticas" entre outros povos amazônicos, vide, por exemplo, o caso Shipibo-Conibo descrito por Gebhart-Sayer $(1985,1986)$.

${ }^{14}$ É importante lembrar que nos rituais de Kawoká não há apenas beleza, mas também temor (que pode acidentalmente virar terror), o qual não deixa de ser esteticamente apreciado enquanto beleza. O fato de as mulheres não verem os rituais de flautas não significa que elas não participem deles e nem que um plano de percepções e emoções não seja compartilhado. O temor é secundário em relação à beleza. É realmente tão secundário que alguns Wauja questionam a interdição visual imposta às mulheres. 


\section{Referências bibliográficas}

AGOSTINHO, Pedro. 1974. Kwarìp. Mito e ritual no Alto Xingu. São Paulo: EDUSP.

ÅRHEM，Kaj. 1996. "The cosmic food web: human-nature relatedness in the Northwest Amazon". In: P. Descola e G. Pálsson (orgs.), Nature and society: anthropological perspectives. London: Routledge. pp. 185-203.

BARCELOS NETO, Aristóteles. 2001. "O universo visual dos xamãs wauja (Alto Xingu)". Journal de la Société des Americanistes, 87:137-161. 2002. A arte dos sonhos: uma iconografia ameríndia. Lisboa: Assírio \& Alvim.

2003. "Festas para um 'nobre': ritual e (re)produção sociopolítica no Alto Xingu". Estudios Latinoamericanos, 23:63-90.

. 2004a. Visiting the Wauja Indians: masks and other living objects from an Amazonian collection. Lisboa: Museu Nacional de Etnologia.

2004b. "As máscaras rituais do Alto Xingu um século depois de Karl von den Steinen". Bulletin de la Société Suisse des Américanistes, 68:51-71.

2004c. "Processo criativo e apreciação estética no grafismo wauja". Cadernos de Campo, 12:87-108. . No prelo. Apapaatai: rituais de máscaras no Alto Xingu. São Paulo: EDUSP/ FAPESP.

. 2006. "'Doença de índio': o princípio patogênico da alteridade e os modos de transformação em uma cosmologia amazônica". Campos - Revista de Antropologia Social 7(1):9-34.

BASSO, Ellen Becker. 1973. The Kalapalo Indians of Central Brazil. New York: Holt, Rinhehart \& Winston.
CARNEIRO, Robert. 1977. "Recent observations on shamanism and witchcraft among the Kuikuro Indians of Central Brazil". Annals of the New York Academy of Sciences, 293:215-228.

. "Quarup: a festa dos mortos no

Alto Xingu". In: V. Penteado Coelho (org.), Karl von den Steinen: um século de antropologia no Xingu. São Paulo: EdUSP. pp. 405-429.

COELHO DE SOUZA, Marcela. 2001 "Virando gente: notas a uma história aweti". In: B. Franchetto e M. Heckenberger (orgs.), Os povos do Alto Xingu: história e cultura. Rio de Janeiro: Editora UFRJ. pp. 360-402.

FAUSTO, Carlos. 2001. Inimigos fiéis: história, guerra e xamanismo na Amazônia. São Paulo: EDUSP. . 2002. "Banquete de gente: comensalidade e canibalismo na Amazônia". Mana. Estudos de Antropologia Social, 8(2):7-44.

FÉNELON COSTA, Maria Heloísa 1988. O mundo dos Mehináku e suas representações visuais. Brasília: Editora da UnB.

GEBHART-SAYER, Angelika. 1985. "The geometric desings of the ShipiboConibo in ritual context". Journal of Latin American Lore, 11(2):143-175. . 1986. "Una terapia estética: los diseños visionarios del ayahuasca entre los Shipibo-Conibo". America Indígena, 46:189-218.

GELL, Alfred. 1998. Art and agency: an anthropological theory. Oxford: Oxford University Press.

GREGOR, Thomas. 1977. Mehinaku the drama of daily life in a Brazilian Indian village. Chicago: University of Chicago Press.

. 2001. "Casamento, aliança e paz intertribal". In: B. Franchetto e M. 
Heckenberger (orgs.), Os povos do Alto Xingu: história e cultura. Rio de Janeiro: Editora UFRJ. pp. 175-192.

HECKENBERGER, Michael. 1999. "O enigma das grandes cidades: corpo privado e estado na Amazônia". In: A. Novaes (org.), A outra margem do Ocidente. São Paulo: Companhia das Letras. pp. 125-152.

2001. "Estrutura, história e transformação: a cultura xinguana na longue durée, 1000-2000 d.C.". In: B. Franchetto e M. Heckenberger (orgs.), Os povos do Alto Xingu: história e cultura. Rio de Janeiro: Editora UFRJ. pp. 21-62.

IRELAND, Emilienne Marie. 1986. "Our chiefs do not spill their anger: covert leadership in political decisions". Comunicação apresentada na $85^{\mathrm{a}}$ Reunião da AAA, sessão "Political Structure and Law of Autocracies and Dictatorships", Filadelfia. Ms.

. 1988. "Killing a public menace or a private enemy? Revenge and witchcraft execution". Comunicação apresentada na $87^{a}$ Reunião da AAA, sessão "Murder, Feud, and Revenge", Fenix. Ms.

1993. "Witchcraft accusations and political succession in a Xingu society". Comunicação apresentada na Conferência "Lowland South America Indians", Bennington College, Bennington. Ms.

1996. "Upper Xingu politics in historical context". Comunicação apresentada no Grupo de Trabalho "Alto Xingu, uma perspectiva histórica: pré-história, história, indagação científica e futuro sócio-político", XX Reunião Brasileira de Antropologia, Salvador. Ms.

LIMA, Tânia Stolze. 1996. "O dois e seu múltiplo: reflexões sobre o perpectivismo em uma cosmologia tupi". Mana. Estudos de Antropologia Social, 2(2):21-47.
2002. "A paixão dos espíritos". Conferência apresentada no Departamento de Antropologia da Universidade de São Paulo. Ms.

MENEZES BASTOS, Rafael José de. 1990. A festa da jaguatirica: uma partitura crítico-interpretativa. Tese de Doutorado em Antropologia Social, Universidade de São Paulo.

1995. "Indagação sobre os Kamayurá, o Alto Xingu e outros nomes e coisas: uma etnologia da sociedade xinguara". Anuário Antropológico, 94:227-269.

MENGET, Patrick. 1985. "Guerre, sociétés et vision du monde dans les basses terres de L'Amérique du Sud. Jalons pour une étude comparative". Journal de la Société des Américanistes, 71:131-142.

1993. "Les frontières de la chefferie: remarques sur le système politique du Haut Xingu (Brésil)". L'Homme, 126-128(2-4):59-76.

MONTARDO, Deise. 2001. "O fazerse de um belo guerreiro: música e dança no Jeroky guarani". Trabalho apresentado na IV Reunião de Antropologia do Mercosul, Curitiba. Ms.

. 2002. Através do mbaraka: música e xamanismo guarani. Tese de Doutorado em Antropologia Social, Universidade de São Paulo.

REICHEL-DOLMATOFF, Gerardo. 1975. The shaman and the jaguar: a study of narcotic drugs among the Indians of Colombia. Philadelphia: Temple University Press.

RODGERS, David. 2002. "A soma anômala: a questão do suplemento no xamanismo e menstruação ikpeng". Mana. Estudos de Antropologia Social, 8(2):91-125.

SILVERWOOD-COPE, Peter. 1990. Os Maku: povo caçador do noroeste da Amazônia. Brasília: Editora da Universidade de Brasília. 
STEINEN, Karl von den. 1886. Durch Central Brasilien. Leipzig: Brockhaus.

SZTUTMAN, Renato. 2000. Caxiri, a celebração da alteridade: ritual e comunicação na Amazônia indígena. Dissertação de Mestrado em Antropologia Social, Universidade de São Paulo.

2005. O profeta e o principal. A ação política ameríndia e seus personagens. Tese de Doutorado em Antropologia Social, Universidade de São Paulo.

TEIXEIRA-PINTO, Márnio. 2004. “Entre uns e outros: relação, diferença e transformação entre os Arara (Caribe)". Comunicação apresentada no Fórum de Pesquisa "Transformações Indígenas: Modos e Regimes Ameríndios de Alteração e Segmentação", XXIV Reunião Brasileira de Antropologia/ ABA, Recife. Ms.

VIVEIROS DE CASTRO, Eduardo. 1977. Indivíduo e sociedade no Alto Xingu: os Yawalapíti. Dissertação de Mestrado em Antropologia Social, PPGAS/Museu Nacional/ UFRJ.

1979. "A fabricação do corpo na sociedade xinguana". Boletim do $\mathrm{Mu}$ seu Nacional, 32:40-49.

1986. Araweté: os deuses canibais. Rio de Janeiro: Zahar/ ANPOCS.

. 2002a. "Perspectivismo e multinaturalismo na América indígena". In: A inconstância da alma selvagem e outros ensaios de antropologia. São Paulo: Cosac \& Naify. pp. 345-399. 2002b. "Atualização e contraefetuação do virtual: o processo do parentesco". In: A inconstância da alma selvagem e outros ensaios de antropologia. São Paulo: Cosac \& Naify. pp. 401-456.

. 2002c. "Esboço de cosmologia yawalapíti". In: A inconstância da alma selvagem e outros ensaios de antropologia. São Paulo: Cosac \& Naify. pp. 25-85. 
Resumo

O artigo explora as diferenças e as relações entre feitiçaria e xamanismo entre os Wauja do Alto Xingu com ênfases nos processos de transformações corporais, nas noções de agência letal e na ontologia da predação. A feitiçaria é descrita como uma categoria de acusação de assassinato e de responsabilidade por malefícios de diversas ordens e como um dispositivo de contrapoder no cenário de chefias fortes e relativamente autoritárias. As acusações, sobretudo as de assassinato, tecem uma urdidura política que traz a feitiçaria para o centro da socialidade wauja. A hipótese principal é a de que a feitiçaria tenha um duplo efeito político, simultâneo ou sucessivo, na paisagem sociológica wauja: ela pode servir para perseguir, eliminar ou exilar os adversários de um chefe, bem como pode se voltar contra este para contestar seu status e comprometer seu prestígio. Tem também um duplo sentido estético: é a encarnação mais perfeita da fealdade e da tristeza-morte, por isso, profundamente oposta ao ritual e à matéria própria das realizações terapêuticas que caracterizam o xamanismo xinguano.

Palavras-chave: Feitiçaria, Xamanismo, Índios Wauja, Categorias de acusação, Estética.

\section{Abstract}

This article discusses the differences and relations between witchcraft and shamanism among the Wauja Indians of the Upper Xingu river, focusing on the processes of body transformations, notions of lethal agency and the ontology of predation. Witchcraft is described as an accusation category referencing murder and also as an anti-power apparatus in the context of strong and relatively authoritarian chieftainships. Accusations, especially those of murder, weave a political plot that brings witchcraft to the center of Wauja sociality. Our main hypothesis is that witchcraft has a double political effect (simultaneous or successive) in the Wauja sociological landscape: it can serve to persecute, eliminate, or exile a chief's adversaries, but it also may turn against a chief, compromising his prestige and contesting his status. Witchcraft also has a double aesthetic effect: it is the most perfect incarnation of ugliness and of sadness/death and is thus opposed to ritual and to the very materials of the therapeutic projects that characterize Xinguano shamanism.

Key words: Witchcraft, Shamanism, Wauja Indians, Accusation categories, Aesthetics. 